\title{
PENGARUH PENDEKATAN PEMBELAJARAN TERHADAP NILAI PENGETAHUAN DAN KETERAMPILAN SEJARAH INDONESIA (Eksperimen pada Siswa SMA Swasta di Jakarta Timur)
}

\author{
Siti Wahyuni \\ Dosen Program Studi Pendidikan Ilmu Pengetahuan Sosial Universitas Indraprasta PGRI \\ Email : sitiwahyuni.unindra@gmail.com
}

\begin{abstract}
Abstrak
Penelitian bertujuan untuk menganalisis dan menguji kebenaran hipotesis mengenai pengaruh pendekatan pembelajaran terhadap nilai pengetahuan dan keterampilan sejarah Indonesia siswa. Hipotesis penelitian yaitu: 1) Pengaruh Pendekatan Pembelajaran terhadap Nilai Pengetahuan dan Keterampilan Sejarah Indonesia secara Multivariat. 2) Pengaruh Pendekatan Pembelajaran terhadap Nilai Pengetahuan Sejarah Indonesia. 3) Pengaruh Pendekatan Pembelajaran terhadap Nilai Keterampilan Sejarah Indonesia. Metode penelitian adalah metode eksperimen. Populasi adalah siswa kelas X Sekolah Menegah Atas (SMA) Swasta di Jakarta Timur dengan besar sampel sebanyak 70 siswa yang terdiri dari 35 siswa kelas eksperimen dan 35 siswa kelas kontrol, teknik sampling yang digunakan yaitu random cluster sampling. Pengumpulan data dilaksanakan dengan pemberian tes pengetahuan dan tes keterampilan setelah selesai pembelajaran. Analisis data terdiri dari pengujian instrumen pengetahuan dan keterampilan sejarah Indonesia dengan uji validitas, reliabilitas, indek kesukaran dan daya beda. Selanjutnya dilakukan uji prasyarat analisis data dengan uji normalitas dan uji homogenitas. Pengujian hipotesis dengan teknik Manova (Multivariate Analysis of Varians) dengan bantuan IMB SPSS Versi 20.

Hasil pengujian hipotesis diperoleh simpulan sebagai berikut: 1) Terdapat pengaruh yang signifikan pendekatan pembelajaran terhadap nilai pengetahuan dan keterampilan sejarah Indonesia siswa SMA Swasta di Jakarta Timur secara multivariate, hal ini dibuktikan dengan nilai sig. sebesar $0,000<$ 0,05 dan $F_{\text {hitung }}=12,566$. 2) Terdapat pengaruh yang signifikan pendekatan pembelajaran terhadap nilai pengetahuan sejarah Indonesia siswa SMA Swasta di Jakarta Timur, hal ini dibuktikan dengan nilai sig sebesar $0,001<0,05$ dan $F_{\text {hitung }}=11,455$. 3) Terdapat pengaruh yang signifikan pendekatan pembelajaran terhadap nilai keterampilan sejarah Indonesia siswa SMA Swasta di Jakarta Timur, hal ini dibuktikan dengan nilai sig sebesar $0,000<0,05$ dan $F_{\text {hitung }}=14,368$.

Kata kunci : pendekatan pembelajaran, nilai pengetahuan, nilai keterampilan, manova (multivariate analysis of varians).
\end{abstract}

\section{PENDAHULUAN}

Perbedaan penilaian antara KTSP dan kurikulum 2013 yaitu terletak pada penilaian yang sebelumnya hanya aspek kognitifnya dan afektifnya saja menjadi fokus penilaian pada kurikulum 2013 lebih pada penggabungan keterkaitan antara aspek kognitif, psikomotorik dan afektif yang tertuang dalam kompetensi inti (KI) sikap spiritual (KI 1), kompetensi inti (KI) sikap sosial (KI 2), kompetensi inti (KI) aspek pengetahuan (KI 3) dan kompetensi inti (KI) aspek ketrampilan (KI 4). Dari 4 (empat) kompetensi inti tersebut wajib diterapkan oleh guru dalam proses kegiatan belajar mengajar agar tujuan dari kurikulum 2013 tercapai yaitu peningkatan kualitas pendidikan nasional dari segi sikap spiritual, sikap social, pengetahuan dan ketrampilan 
menuju pendidikan yang berkarakter. Keefektifan dan keefisienan sebuah pembelajaran diukur dari tingkat pemahaman materi oleh siswa yang berujung pada peningkatan prestasi belajar dari aspek pengetahuan dan ketrampilan siswa. Untuk itu peran guru adalah memilih pendekatan pembelajaran yang sesuai, yang mampu membawa siswa kepada pencapaian prestasi yang setinggi-tingginya. Kenyataan di Jakarta Timur, guru masih menggunakan model pembelajaran ekspositori/Konvesional pembelajaran masih berpusat pada guru (teacher center). Hal ini berdampak kepada pencapaian prestasi siswa yang kurang maksimal. Untuk mencapai tujuan pembelajaran ekonomi secara efektif guru dianjurkan untuk beralih dari pendekatan ekspositori dan menerapkan metode pembelajaran yang inovatif.

Pembelajaran inovatif berarti bahwa pembelajaran dikemas oleh guru atau instruktur lainnya yang merupakan wujud gagasan atau teknik yang dipandang baru agar memfasilitaskan siswa untuk memperoleh kemajuan dalam proses dan hasil belajar. Salah satu pendekatan pembelajaran yang dianjurkan yakni, pendekatan saitifik. Dalam pendekatan saintifik menjadikan siswa yang diberi tahu menjadi siswa yang mencari tahu, dari guru yang merupakan sumber belajar menjadi belajar dari beraneka macam sumber, dari pendekatan tekstual menuju proses sebagai penguatan penggunaan pendekatan ilmiah, dari pembelajaran yang menekankan jawaban tunggal menuju pembelajaran dengan jawaban yang kebenarannya multi dimensi, pembelajaran yang mengutamakan pembudayaan dan pemberdayaan peserta didik sebagai pembelajar sepanjang hayat.

Penilaian aspek pengetahuan dan keterampilan sejarah diperoleh melalui kegiatan mengamati, menanya, menalar, menyaji, dan mencipta, dari keterampilan tersebut harus mendorong siswa untuk melakukan proses pengamatan hingga penciptaan. Untuk mewujudkan keterampilan tersebut perlu melakukan pembelajaran yang menerapkan metode belajar yang berbasis penelitian dan pembelajaran yang menghasilkan karya dan pemecahan masalah. Dengan demikian maka pembelajaran sejarah harus mampu untuk membuat suatu karya misalnya melakukan suatu tugas proyek tentang teori-teori masuknya islam di Indonesia. Keterampilan dalam pembelajaran sejarah harus semakin ditingkatkan karena pemikiran masyarakat dan para siswa yang memandang bahwa sejarah merupakan pelajaran yang membuat ngantuk serta lebih focus pada hafalan pada kenyataannya hal tersebut tidak sepenuhnya benar. 
Pelajaran sejarah bukan hanya berbicara mengenai apa, dimana, kapan, akan tetapi harus mampu menjawab mengapa dan bagaimana. Untuk menjawab mengenai pertanyaan mengapa dan bagaimana maka diperlukan suatu pemikiran yang tinggi karena hal ini berhubungan dengan cara siswa menganalisis suatu peristiwa. Seorang guru sejarah harus mampu memunculkan suatu pembahasan yang berkaitan dengan bagaimana karakteristik kehidupan masyarakat, pemerintahan dan kebudayaan pada masa kerajaan islam di Indonesia. Dalam penyajiannya seorang guru sejarah bisa menggunakan media yang berkaitan dengan hal tersebut, contohnya menyajikan gambar-gambar tentang peninggalan budaya islam di indonesia, dengan hal tersebut siswa akan mampu dibawa pada situasi saat itu dan sejarah tidak akan membosankan dengan penggunaan media pembelajaran yang variatif.

Mata pelajaran Sejarah Indonesia bukan berisi materi pembelajaran yang dirancang hanya untuk mengasah kompetensi pengetahuan peserta didik saja. Sejarah Indonesia adalah mata pelajaran yang membekali peserta didik dengan pengetahuan tentang dimensi ruang-waktu perjalanan sejarah Indonesia, keterampilan dalam menyajikan pengetahuan yang dikuasainya secara konkret dan abstrak, serta sikap menghargai jasa para pahlawan yang telah meletakkan pondasi bangunan negara Indonesia beserta segala bentuk warisan sejarah, baik benda maupun bukan benda. Sehingga terbentuk pola pikir peserta didik yang sadar sejarah dari hal tersebut terlihat bahwa menanamkan jiwa nasionalisme dan patriotik serta cinta tanah air menjadi fokus pembelajaran sejarah Indonesia.

Berdasarkan hal tersebut maka guru sejarah harus mampu mengolah perencanaan pembelajaran secara kreatif serta inovatif di kelas, Sesuai dengan pendekatan yang digunakan dalam Kurikulum 2013, peserta didik diajak menjadi berani untuk mencari sumber belajar lain yang tersedia dan terbentang luas di sekitarnya. Peran guru dalam meningkatkan dan menyesuaikan daya serap peserta didik dengan ketersediaan kegiatan belajar mengajar sangat penting. Guru dapat memperkayanya dengan kreasi dalam bentuk kegiatan-kegiatan lain yang sesuai dan relevan yang bersumber dari lingkungan sosial dan alam. Seorang guru harus mampu melakukan perubahan dan pengembangan dalam setiap pembelajaran, artinya seorang guru tidak monoton dalam proses belajar mengajar dan mempunyai inovasi dalam menggunakan pendekatan pembelajaran yang relevan dengan tuntutan perkembangan zaman. Tidak 
semua pendekatan pembelajaran tepat digunakan untuk semua materi pembelajaran. Pendekatan pembelajaran tertentu hanya tepat digunakan untuk materi pembelajaran tertentu. Sebaliknya materi pembelajaran tertentu akan dapat berhasil maksimal jika menggunakan pendekatan pembelajaran tertentu.

\section{TINJAUAN PUSTAKA}

\section{Pengertian Mata Pelajaran Sejarah Indonesia}

Dalam desain Kurikulum 2013, yakni munculnya mata pelajaran Sejarah Indonesia sebagai mata pelajaran wajib pada struktur organisasi isi untuk jenjang SMA/MA/SMK/MAK (yang selanjutnya disebut SMA dan yang sederajat). Semua peserta didik di jenjang SMA dan yang sederajat itu harus menempuh mata pelajaran Sejarah Indonesia. Di samping itu masih ada mata pelajaran Sejarah bagi peserta didik yang mengambil peminatan rumpun Ilmu Sosial.

Menurut Hasan (2005: 2) bahwa dalam kedudukannya sebagai mata pelajaran yang berdiri sendiri, mata pelajaran Sejarah ditunjuk untuk memberikan pengetahuan dan pemahaman tentang bangsa beserta keseluruhan identitas, tetapi juga untuk menjadi alat dalam mengkaji kehidupan masa kini. Dengan kedudukan sebagai social studies, tujuan agar apa yang dipelajari tersebut berguna dalam kehidupan masa kini tetap menonjol, artinya dengan demikian kurikulum sejarah untuk memberikan alat dan memampuan yang dapat digunakan peserta didik bagi kehidupannya sehari-hari.

Muhammad Nuh (dalam Amuwarni Dwi, dkk. 2014: 3) mengemukakan bahwa sejarah Indonesia adalah mata pelajaran yang membekali peserta didik dengan pengetahuan tentang dimensi ruang-waktu perjalanan sejarah Indonesia, keterampilan dalam menyajikan pengetahuan yang dikuasainya secara konkret dan abstrak, serta sikap menghargai jasa para pahlawan yang telah meletakkan pondasi bangunan negara Indonesia beserta segala bentuk warisan sejarah, baik benda maupun tak benda, sehingga terbentuk pola pikir peserta didik yang sadar sejarah, sejarah Indonesia bukan berisi materi pembelajaran yang dirancang hanya untuk mengasah kompetensi pengetahuan siswa.

\section{Aspek Pengetahuan dan Keterampilan Mata Pelajaran Sejarah Indonesia}

Penilaian dalam kurikulum 2013 ditekankan pada penilaian otentik. Hasil belajar kegiatan belajar yang berupa kemampuan kognitif dan psikomotor ditentukan oleh 
kondisi peserta didik. Kualitas pendidikan sangat ditentukan oleh kemampuan seorang guru dalam mengelola proses pembelajaran di kelas.

Penilaian otentik adalah proses pengumpulan informasi oleh guru tentang perkembangan dan pencapaian pembelajaran yang dilakukan anak didik melalui berbagai teknik yang mampu mengungkapkan, membuktikan atau menunjukkan secara tepat bahwa tujuan pembe pembelajaran dan kemampuan (kompetensi) telah benarbenar dikuasai dan dicapai (Abdul Majid, 2009: 186).

Amuwarni Dwi, dkk. (2013: 18) menyatakan bahwa prinsip-prinsip penilaian dalam mata pelajaran Sejarah Indonesia kelas X antara lain:

1) Menentukan aspek dari hasil belajar sejarah yang sudah dan belum dikuasai peserta didik setelah suatu proses pembelajaran.

2) Umpan balik bagi peserta didik untuk memperbaiki hasil belajar yang kurang atau belum dikuasai.

3) Umpan balik bagi guru untuk memberikan bantuan bagi peserta didik yang mengalami masalah dalam penguasaan pengetahuan, kemampuan, nilai, dan sikap.

4) Umpan balik bagi guru untuk memperbaiki perencanaan pembelajaran berikutnya.

5) Aspek-aspek yang dinilai/dievaluasi mencakup:

a) pengetahuan dan pemahaman tentang peristiwa sejarah

b) kemampuan mengomunikasikan pemahaman mengenai peristiwa sejarah dalam bahasa lisan dan tulisan

c) kemampuan menarik pelajaran/nilai dari suatu peristiwa sejarah, kemampuan menerapkan pelajaran/nilai yang dipelajari dari peristiwa sejarah dalam kehidupan sehari-hari

d) kemampuan melakukan kritik terhadap sumber dan mengumpulkan informasi dari sumber

e) kemampuan berfikir historis dalam mengaji berbagai peristiwa sejarah dan peristiwa politik, sosial, budaya, ekonomi yang timbul dalam kehidupan keseharian masyarakat dan bangsa; pemahaman tentang semangat kebangsaan dan menerapkannya dalam kehidupan bermasyarakat, berbangsa, dan bernegara. Prinsip penilaian hasil belajar yang tercantum dalam lampiran peraturan menteri pendidikan dan kebudayaan nomor 23 tahun 2016 adalah sebagai berikut: 
1) Sahih, berarti penilaian didasarkan pada data yang mencerminkan kemampuan yang diukur;

2) Objektif, berarti penilaian didasarkan pada prosedur dan kriteria yang jelas, tidak dipengaruhi subjektivitas penilai;

3) Adil, berarti penilaian tidak menguntungkan atau merugikan peserta didik karena berkebutuhan khusus serta perbedaan latar belakang agama, suku, budaya, adat istiadat, status sosial ekonomi, dan gender.

4) Terpadu, berarti penilaian merupakan salah satu komponen yang tak terpisahkan dari kegiatan pembelajaran;

5) Terbuka, berarti prosedur penilaian, kriteria penilaian, dan dasar pengambilan keputusan dapat diketahui oleh pihak yang berkepentingan;

6) Menyeluruh dan berkesinambungan, berarti penilaian mencakup semua aspek kompetensi dengan menggunakan berbagai teknik penilaian yang sesuai, untuk memantau dan menilai perkembangan kemampuan peserta didik;

7) Sistematis, berarti penilaian dilakukan secara berencana dan bertahap dengan mengikuti langkah-langkah baku;

8) Beracuan kriteria, berarti penilaian didasarkan pada ukuran pencapaian kompetensi yang ditetapkan; dan akuntabel, berarti penilaian dapat dipertanggungjawabkan, baik dari segimekanisme, prosedur, teknik, maupun hasilnya.

Mekanisme penilaian aspek pengetahuan dan keterampilan dilakukan melalui tes tertulis, tes lisan, dan penugasan sesuai dengan kompetensi yang dinilai; penilaian keterampilan dilakukan melalui praktik, produk, proyek, portofolio, dan/atau teknik lain sesuai dengan kompetensi yang dinilai. Penilaian aspek pengetahuan dilakukan melalui tahapan:

1) menyusun perencanaan penilaian;

2) mengembangkan instrumen penilaian;

3) melaksanakan penilaian;

4) memanfaatkan hasil penilaian; dan

5) melaporkan hasil penilaian dalam bentuk angka dengan skala 0-100 dan deskripsi.

\section{Hakekat Pendekatan Pembelajaran Saintifik}

Pendekatan pembelajaran ilmiah menekankan pada pentingnya kolaborasi dan kerja sama di antara peserta didik. Pendekatan saintifik merupakan salah satu 
pendekatan pembelajaran ilmiah. Hamruni (2012: 6) menyatakan bahwa pendekatan adalah konsep dasar yang mewadahi, menginspirasi, menguatan, dan melatari pemikiran tentang bagaimana metode pembelajaran diterapkan berdasarkan teori tertentu. Oleh karena itu banyak pandangan yang menyatakan bahwa pendekatan sama artinya dengan metode.

Daryanto (2014: 51) mengungkapkan bahwa pembelajaran dengan pendekatan saintifik adalah proses pembelajaran yang dirancang sedemikian rupa agar peserta didik secara aktif mengkonstruksi konsep, hukum atau prinsip melalui tahapantahapan mengamati, merumuskan masalah, mengajukan atau merumuskan hipotesis, mengumpulkan data dengan berbagai teknik, menganalisis data, menarik kesimpulan dan mengkomunikasikan konsep, hukum atau prinsip yang ditemukan. Sedangkan menurut Abdul Majid (2014: 193) mengungkapkan bahwa penerapan pendekatan saintifik bertujuan untuk pemahaman kepada peserta didik dalam mengenal, memahami berbagai materi menggunakan pendekatan ilmiah, bahwa informasi bisa berasal dari mana saja, kapan saja, tidak bergantung pada informasi searah dari guru.

Pada Kurikulum 2013 sejalan dengan kompetensi inti, maka peserta didik dituntut untuk memiliki keterampilan mengolah, menalar (yang dapat diartikan berpikir kritis), memecahkan masalah, dan pada akhirnya mampu menyajikannya dalam ranah konkret maupun abstrak konsep-konsep keilmuan yang telah didapat sebelumnya. untuk pencapaian tersebut maka proses pembelajaran dilaksanakan melalui lima tahapan pendekatan saintifik (scientific approach) yang dimulai dari mengamati, menanya, menalar, mencoba, dan membuat jaringan (berkolaboratif).

Pendekatan saintifik dimaksudkan untuk memberikan pemahaman kepada peserta didik dalam mengenal, memahami berbagai materi menggunakan pendekatan ilmiah, bahwa informasi bisa berasal dari mana saja, kapan saja, tidak bergantung pada informasi searah dari guru. Oleh karena itu kondisi pembelajaran yang diharapkan tercipta diarahkan untuk mendorong peserta didik dalam mencari tahu dari berbagai sumber melalui observasi, dan bukan hanya diberi tahu. Pada proses pencarian pengetahuan dari pada transfer pengetahuan, peserta didik dipandang sebagai subjek belajar yang perlu dilibatkan secara aktif dalam proses pembelajaran, guru hanyalah seorang fasilitator yang membimbing dan mengkoordinasikan kegiatan belajar. 
Jadi dapat disimpulkan bahwa pendekatan saintifik adalah pembelajaran yang terdiri atas kegiatan mengamati (untuk mengidentifikasi hal-hal yang ingin diketahui), merumuskan pertanyaan (dan merumuskan hipotesis), mencoba/mengumpulkan data (informasi) dengan berbagai teknik, mengasosiasi/ menganalisis/mengolah data (informasi) dan menarik kesimpulan serta mengkomunikasikan hasil yang terdiri dari kesimpulan untuk memperoleh pengetahuan, keterampilan dan sikap. Langkah-langkah tersebut dapat dilanjutkan dengan kegiatan mencipta. Pendekatan saintifik merupakan pendekatan yang berpusat kepada siswa agar siswa secara aktif mengkonstruksi konsep, hukum atau prinsip melalui tahapantahapan mengamati, merumuskan masalah, mengajukan atau merumuskan hipotesis, mengumpulkan data dengan berbagai teknik, menganalisis data, menarik kesimpulan dan mengkomunikasikan konsep, hukum atau prinsip yang ditemukan.

\section{Hakekat Pendekatan Pembelajaran Ekspositori}

Pendekatan Ekspositori menekankan pada penyampaian informasi yang disampaikan sumber belajar kepada warga belajar. Melalui pendekatan ini sumber belajar dapat menyampaikan materi sampai tuntas. Pendekatan Ekpositori lebih tepat digunakan apabila jenis bahan belajar yang bersifat informatif yaitu berupa konsepkonsep dan prinsip dasar yang perlu dipahami warga belajar secara pasti. Pendekatan ini juga tepat digunakan apabila jumlah warga belajar dalam kegiatan belajar itu relatif banyak.

Surtikanti (2008: 49) menyatakan bahwa pendekatan pembelajaran ekspositori merupakan kegiatan mengajar yang berpusat pada guru dimana guru memberikan informasi, menerangkan suatu konsep, mendemontrasikan keterampilannya mengenai pola, aturan, dalil, memberi kesempatan siswa bertanya, guru memberikan contoh soal dan siswa diminta mengerjakan soal secara individual atau kelompok.

Sedangkan menurut Dimyati dan Mudjiono (2006: 172) bahwa pendekatan ekspositori merupakan "pembelajaran yang menekankan kepada proses penyampaian materi secara langsung dari seorang guru kepada siswanya dengan maksud agar siswa dapat menguasai materi pembelajaran secara optimal. Untuk itu, karakteristik khusus pada pendekatan ekspositori, yakni guru lebih mendominasi kegiatan dengan mengontrol alur pelajaran melalui penyampaian informasi dan demonstrasi untuk menyelesaikan suatu soal. 


\section{METODE}

Metode penelitian adalah metode eksperimen. Populasi adalah siswa kelas X Sekolah Menegah Atas (SMA) Swasta di Jakarta Timur dengan besar sampel sebanyak 70 siswa yang terdiri dari 35 siswa kelas eksperimen dan 35 siswa kelas kontrol, teknik sampling yang digunakan yaitu random cluster sampling. Pengumpulan data dilaksanakan dengan pemberian tes pengetahuan dan tes keterampilan setelah selesai pembelajaran. Analisis data terdiri dari pengujian instrumen pengetahuan dan keterampilan sejarah Indonesia dengan uji validitas, reliabilitas, indek kesukaran dan daya beda. Selanjutnya dilakukan uji prasyarat analisis data dengan uji normalitas dan uji homogenitas. Pengujian hipotesis dengan teknik Manova (Multivariate Analysis of Varians) dengan bantuan IMB SPSS Versi 20. Penelitian ini dilaksanakan pada bulan April s/d Mei 2017.

\section{HASIL DAN PEMBAHASAN}

Terdapat Pengaruh yang Signifikan Pendekatan Pembelajaran terhadap Nilai Pengetahuan dan Keterampilan Sejarah Indonesia secara Multivariat

Setelah dilakukan analisis dengan menggunakan pengujian MANOVA melalui bantuan IBM SPSS Statistik Versi 20 menunjukkan bahwa diterimanya hipotesis $\mathrm{H}_{1}$ yang menyatakan bahwa Terdapat perbedaan yang signifikan penerapan pendekatan pembelajaran saintifik dan Ekspositori terhadap nilai pengetahuan dan keterampilan Sejarah Indonesia siswa secara Multivariate. Hal ini dibuktikan dengan nilai $\mathrm{F}_{\text {hitung }}$ table Multivariate Test menerangkan perbandingan rata-rata perbedaan nilai pengetahuan dan keterampilan sejarah Indonesia siswa anatara dua kelompok pendekatan pembelajaran. Terdapat empat uji statistik yaitu Pillai's Trace, Wilk's Lambda, Hotelling' Trace, dan Ray's Largers. Keempat pengujian ini didasarkan kepada nilai eigen di mana formula untuk masing-masing uji statistik tersebut.

Dari Tabel 4.9 didapat nilai Pillai's Trace positif, yaitu 0,995. Meningkatnya nilai ini memberikan pengaruh yang berarti pada pendekatan pembelajaran atau perbedaan rata-rata yang signifikan anatara kelompok data. Nilai Wilk's Lambda berkisar antara 0 hingga 1, dimana apabila nilai Wilk's Lambda mendekati 0 memberikan arti adanya pengaruh yang signifikan pada pendekatan pembelajaran atau 
adanya perbedaan rata-rata yang berarti antara kelompok data. Sebaliknya nilai Wilk's Lambda mendekati angka 1 berarti tidak ada pengaruh yang berarti pada pendekatan pembelajaran atau tidak ada perbedaan rata-rata yang berarti antara kelompok data. Dari tabel 4.9 di atas nilai Wilk's Lambda 0,005 yang mendekati nol, sehingga dapat dikatakan bahwa terdapat pengaruh yang berarti pada pendekatan pembelajaran terhadap hasil nilai rata-rata nilai pengetahuan dan keterampilan sejarah Indonesia yang berbeda antara dua kelompok pendekatan.

Nilai Hotelling's trace menunjukkan nilai positif, yaitu 213,484. Meningkatnya nilai Hottelling's Trace selalu lebih besar dari nilai Pillai's trace maka nilai Hotellinh's trace diatas menunjukkan adanya pengaruh yang berarti pada pendekatan pembelajaran, akan tetapi dalam beberapa hal bila eigen value bernilai kecil maka nilai Hotelling's trace dan Pillai's trace akan berdekatan. Hal ini menunjukkan sebuah indikasi tidak adanya pengaruh yang berarti pada pendekatan pembelajaran. Nilai Roy's Largest bernilai positif yaitu 213,484, nilai Roy's Largest selalu lebih kecil atau sama dengan nilai Hotelling.s trace, dan nilai ini menunjukkan adanya pengaruh yang berarti pada pendekatan pembelajaran

Pada baris metode pembelajaran pada angka signifikansi yang diuji dengan prosedur pillai,s Trace, Wilk's Lambda, Hotelling, Trace, dan Roy's Largest Root keempat prosedur yang pertama menunjukkan angka signifikansi dibawah 0,05 (yakni 0,000,0.000, 0.000, dan 0.000) maka $\mathrm{H}_{0}$ ditolak, sehingga dapat disimpulkan bahwa nilai ini menunjukkan adanya pengaruh yang berarti pada pendekatan pembelajaran terhadap nilai pengetahuan dan keterampilan sejarah Indonesia siswa. Pendekatan pembelajaran saintifik banyak dipengaruhi oleh aliran belajar kognitif. Menurut aliran belajar ini pada hakikatnya adalah proses mental dan proses berfikir dengan memanfaatkan segala potensi yang dimiliki oleh setiap individu secara optimal. Hal ini sesuai dengan pendapat Kurt Lewin (dalam Sanjaya, 2010: 195) bahwa teori mental yang dikembangkan oleh Kurt Lewin, menekankan bahwa belajar itu pada dasarnya adalah pengubahan kurikulum kognitif. Selanjutnya Lewin juga menekankan akan pentingnya hadiah dan kesuksesan sebagai factor yang dapat meningkatkan motivasi belajar setiap inividu.

Pemilihan pendekatan pembelajaran yang sesuai dengan tujuan kurikulum dan potensi siswa merupakan kemampuan dan keterampilan dasar yang harus dimiliki oleh 
seorang guru. Hal ini didasari oleh oleh asumsi bahwa ketepatan guru dalam memilih pendekatan pembelajaran akan berpengaruh terhadap keberhasilan dan hasil belajar siswa. Pendekatan pembelajaran yang digunakan guru akan berpengaruh terhadap kualitas proses belajar mengajar dan hasil belajar dan diharapkan mampu meningkatkan kemampuan kognitif dan psikomotorik siswa. Penggunaan pendekatan pembelajaran yang bervariatif akan menjadikan proses kegiatan pembelajaran menjadi lebih aktif dan efektif sehingga mampu merangsang kemampuan siswa dalam menerapkan dan menyajikan setiap tujuan pembelajaran yang disampaikan guru.

Berdasarkan hasil penelitian dan pendapat para ahli dapat disimpulkan bahwa terdapat pengaruh yang signifikan pendekatan pembelajaran terhadap nilai pengetahuan dan keterampilan sejarah Indonesia siswa secara multivariat.

\section{Terdapat Pengaruh yang Signifikan Pendekatan Pembelajaran terhadap Nilai}

\section{Pengetahuan Sejarah Indonesia}

Setelah dilakukan analisis dengan menggunakan pengujian MANOVA melalui bantuan IBM SPSS Statistic Versi 20 berdasarkan hasil pengujian yang terdapat pada tabel 4.10 Test Between Subject Effect terlihat bahwa baris A (pendekatan pembelajaran) - nilai pengetahuan sejarah Indonesia siswa nilai sig 0,001 dan nilai $F_{\text {hitung }}=11,455$. Sedangkan yang menyatakan bahwa terdapat perbedaan yang signifikan penerapan pendekatan pembelajaran saintifik dan ekspositori terhadap nilai pengetahuan sejarah Indonesia siswa.

Tabel Test Between Subject Effect menggambarkan pengujian pendekatan secara univariat. Terlihat nilai signifikan untuk A (pendekatan pembelajaran) - nilai pengetahuan sejarah Indonesia sebesar 0,001 $(<0,05)$. Di dalam proses pembelajaran saintifik mengembangkan keterlibatan siswa secara aktif dalam proses belajar, agar siswa terangsang membangun konsep-konsep dan menetapkan generalisasi-generalisasi. Oleh sebab itu kemampuan menganalisis dan menyajikan konsep-konsep dalam bentuk tulisan maupun lisan sangat diperlukan siswa dalam menghadapi masalah di kemudian hari nanti.

Penelitian ini berhasil menemukan bahwa nilai aspek pengetahuan dan keterampilan sejarah Indonesia siswa yang diajarkan menggunakan pendekatan saintifik lebih tinggi daripada siswa yang diajarkan dengan pendekatan pembelajaran ekpositori. Kesimpulan didukung oleh perolehan statistik deskriptif, yang menunjukkan rerata nilai 
pengetahuan sejarah Indonesia siswa yang diajarkan dengan menggunakan pendekatan saintifik lebih tinggi yaitu sebesar 80,46. Dibandingkan hasil nilai pengetahuan sejarah Indonesia siswa yang diajarkan dengan pendekatan pembelajaran ekspositori sebesar 72,69. Sementara rerata nilai keterampilan sejarah Indonesia siswa yang diajarkan dengan menggunakan pendekatan saintifik lebih tinggi yaitu sebesar 81,49. Dibandingkan hasil nilai pengetahuan sejarah Indonesia siswa yang diajarkan dengan pendekatan pembelajaran ekspositori sebesar 75,60.

Fenomena ini menujukkan bahwa nilai pengetahuan dan keterampilan sejarah Indonesia siswa akan meningkat bila siswa belajar dengan menggunakan pendekatan pembelajaran saintifik. Dalam penelitian ini yang dimaksud dengan nilai pengetahuan adalah hasil interaksi aktif yang menghasilkan ranah kognitif dan nilai keterampilan sejarah Indonesia siswa yaitu pola perubahan tingkah laku dalam menganalisis dan menyajikan serta menguraikan dalam bentuk tulisan dan lisan sebagai ranah psikomotor dan kognitif. Perubahan pola tingkah laku yang menuju kearah yang berkualitas sangat dipengaruhi faktor internal dari diri siswa dan factor eksternal yang terdapat pada lingkungannya. Oleh karena itu sebelum siswa dapa melakukan sesuatu perubahan dalam berkreatifitas maka diperlukan pengetahuan dan keterampilan.

Berdasarkan penelitian ini dan pendapat para ahli, maka dapat disimpulkan bahwa terdapat pengaruh yang signifikan pendekatan pembelajaran terhadap nilai pengetahuan sejarah Indonesia siswa.

\section{Terdapat Pengaruh yang Signifikan Pendekatan Pembelajaran terhadap Nilai}

\section{Keterampilan Sejarah Indonesia}

Setelah dilakukan analisis dengan menggunakan pengujian MANOVA melalui bantuan IBM SPSS Statistik Versi 20 berdasarkan hasil pengujian yang terdapat pada tabel 4.10 Test Between Subject Effect terlihat bahwa baris A (pendekatan pembelajaran) - nilai keterampilan sejarah Indonesia siswa nilai sig 0,000 dan nilai Fhitung $=14,368$. Sedangkan yang menyatakan bahwa terdapat perbedaan yang signifikan penerapan pendekatan pembelajaran saintifik dan ekspositori terhadap nilai keterampilan sejarah Indonesia siswa.

Tabel Test Between Subject Effect menggambarkan pengujian pendekatan secara univariat. Terlihat nilai signifikan untuk A (pendekatan pembelajaran) - nilai keterampilan sejarah Indonesia sebesar 0,000 $(<0,05)$. Penelitian ini mendukung teori 
bahwa pemberian pendekatan pembelajaran dalam proses belajar keterampilan motorik menuntut kemampuan untuk merangkaikan sejumlah gerak-gerak jasmani, maka latihan memegang peranan pokok untuk mendarah dagingkan keterampilan yang sedang dipelajari. Tanpa latihan dan pembiasaan, tidak mungkin orang mengusai keterampilannya (Abdul Majid, 2009: 84).

Pendekatan pembelajaran dalam aspek keterampilan sejarah Indonesia sangat dibutuhkan siswa, karena mata pelajaran sosial pada umumnya dan mata pelajaran sejarah Indonesia pada khususnya mendapat kesempatan lebih untuk mengembangkan pengetahuan dan keterampilannya dalam ilmu sejarah dengan porsi jam yang lebih banyak. hal ini menjadi indikasi bahwa mata pelajaran sejarah mulai naik kelas dan dibangun berdasarkan kemampuan analisis. Masalah dan soal yang disajikan secara bervariasi sehingga masing-masing soal memiliki tingkat keragaman yang tinggi. Soalsoal yang disajikan sebagai tolak ukur pemahaman siswa akan materi yang telah diajarkan harus diselesaikan dengan langkah-langkah yang berbeda, diantaranya dengan menggunakan pendekatan pembelajaran saintifik. Kondisi ini membutuhkan penguasaan guru dalam melaksanakan pembelajaran tersebut dan dicerna serta diterapkan oleh siswa dalam mengkolaborasi berbagai pengalaman dan pengetahuan yang dimiliki. Pendekatan pembelajaran saintifik menuntut guru dan siswa untuk selalu kreatif dalam membuat pembelajaran menyenangkan dan tidak membosankan, sehingga siswa menguasai materi guna mencapai prestasi maksimal.

Di dalam proses pembelajaran saintifik mengembangkan keterlibatan siswa secara aktif dalam proses belajar, agar siswa terangsang membangun konsep-konsep dan menetapkan generalisasi-generalisasi. Oleh sebab itu kemampuan menganalisis dan menyajikan konsep-konsep dalam bentuk tulisan maupun lisan sangat diperlukan siswa dalam menghadapi masalah di kemudian hari nanti. Menurut Daryanto (2014: 78) mengungkapkan bahwa pembelajaran saintifik merupakan aplikasi mencoba atau eksperimen dimaksudkan untuk mengembangkan berbagai ranah tujuan belajar, yaitu sikap, keterampilan, dan pengetahuan.

Dalam penyajian materi hendaknya guru memilih pendekatan, metode, model dan teknik yang banyak melibatkan siswa aktif (student center) dalam belajar. Salah satu pendekatan pembelajaran yang bersifat student center adalah pendekatan pembelajaran saintifik yang dapat membangun kemampuan yang merata pada siswa, 
kemampuan disini adalah kemampuan berfikir untuk mengembangkan pengetahuan nya dalam menghubungkan-hubungkan fakta dan ide untuk mencapai simpulan. Siswa harus memiliki kesempatan berinteraksi dengan sesame anggota, selanjutnya setiap anggota akan bertanggungjawab untuk membantuk anggota kelompok lain yang kurang mampu menguasai materi pelajaran yang sedang dipelajari.

Sedangkan pendekatan pembelajaran ekpositori lebih menekan pada guru hal ini sejalan dengan Surtikanti (2008: 49) menyatakan bahwa pendekatan pembelajaran ekspositori merupakan kegiatan mengajar yang berpusat pada guru dimana guru memberikan informasi, menerangkan suatu konsep, mendemontrasikan keterampilannya mengenai pola, aturan, dalil, memberi kesempatan siswa bertanya, guru memberikan contoh soal dan siswa diminta mengerjakan soal secara individual atau kelompok.

Dari uraian tersebut, dapat diketahui bahwa ada pengaruh yang signifikan pendekatan pembelajaran terhadap keterampilan mata pelajaran sejarah Indonesia.

\section{SIMPULAN DAN SARAN}

Berdasarkan data yang diperoleh, hasil pengujian hipotesis dan pembahasan hasil penelitian, maka dapat disimpulkan :

1. Terdapat pengaruh yang signifikan pendekatan pembelajaran terhadap nilai pengetahuan dan keterampilan sejarah Indonesia Siswa kelas X Sekolah Menengah Atas (SMA) Swasta di Jakarta Timur secara multivariate. Hal ini dibuktikan dengan nilai sig. $0,000<0,05$ dan nilai $F_{\text {hitung }}$ sebesar 12,566.

2. Terdapat pengaruh yang signifikan pendekatan pembelajaran terhadap nilai pengetahuan sejarah Indonesia siswa kelas X SMA Swasta di Jakarta Timur. Hal ini dibuktikan dengan sig. 0,001 <0,05 dan nilai $F_{\text {hitung }}$ sebesar 11,455.

3. Terdapat pengaruh yang signifikan pendekatan pembelajaran terhadap nilai keterampilan sejarah Indonesia siswa kelas X SMA Swasta di Jakarta Timur. Hal ini dibuktikan dengan sig. 0,000 $<0,05$ dan nilai Fhitung sebesar 14,368.

Berdasarkan hasil penelitian ditemukan bahwa terdapat pengaruh yang signifikan pendekatan pembelajaran saintifik dan pendekatan pembelajaran ekspositori terhadap nilai pengetahuan dan keterampilan sejarah Indonesia siswa. Dalam kurikulum 2013 dimana semua aspek mendapatkan porsi yang sama baik aspek sikap spiritual, aspek social, aspek pengetahuan dan aspek keterampilan. Untuk mencapai porsi yang 
sama pada keempat aspek tersebut perlu dikembangkannya keterampilan tingkat tinggi yang meliputi penyajian dalam bentuk tulisan maupun lisan, keterampilan ini yang dilatih dalam pendekatan pembelajaran saintifik. Hendaknya seorang guu sejarah dapat menerapkan pendekatan pembelajaran di sertakan dengan model pembelajaran yang beragam untuk memotivasi siswa sehingga diharapkan mampu meningkatkan nilai siswa dan meningkatkan cara berfikir siswa dalam menyelesaikan soal-soal sejarah.

Pendekatan pembelajaran saintifik merupakan pendekatan yang berpusat kepada siswa agar siswa secara aktif mengkonstruksi konsep, hukum atau prinsip melalui tahapantahapan mengamati, merumuskan masalah, mengajukan atau merumuskan hipotesis, mengumpulkan data dengan berbagai teknik, menganalisis data, menarik kesimpulan dan mengkomunikasikan konsep, hukum atau prinsip yang ditemukan. Pendekatan saintifik ini sangat baik dilaksanakan, dimana dalam pelaksanaan pembelajaran siswa diajak beraktifitas secara langsung dan berinteraksi untuk saling memotivasi, kerjasama dalam diskusi dalam memahami suatu materi pelajaran dengan bantuan bahan ajar atau lembar kerja yang disiapkan oleh guru. Namun ada beberapa hal yang perlu diperhatikan dalam menerapkan pendekatan pembelajaran saintifik, dimana guru yang tidak bisa mengelola waktu dengan baik dan tidak mempunyai bahan ajar yang akan di sampaikan serta penguasaan kelas saat diskusi dan presentasi, guru akan mengalami kesulitan dalam menerapkan pendekatan pembelajaran ini. Hal inilah yang menjadi salah satu sebab guru masih menerapkan pendekatan ekspositori, oleh karena itu untuk menerapkan pendekatan saintifik, sebelum melakukan proses kegiatan belajar mengajar guru harus terlebih dahulu membuat perencanaan pembelajaran agar pada saat pelaksanaan berjalan dengan baik, maka perlu dibuat alokasi waktu yang tepat dan efektif serta efisien.

Berdasarkan pada simpulan penelitian, maka berikut ini diajukan beberapa saran untuk perbaikan nilai pengetahuan dan keterampilan sejarah Indonesia siswa sebagai berikut :

1. Disarankan bagi guru, dalam upaya meningkatkan pengetahuan dan keterampilan sejarah Indonesia siswa dengan pendekatan pembelajaran saintifik merupakan pendekatan pembelajaran yang cukup efektif untuk menumbuhkan, merangsang, serta menambah kemampuan pengetahuan dan keterampilan sejarah Indonesia siswa. Dalam pembagian kelompok belajar hendaknya setiap kelompok belajar 
didampingi oleh siswa yang memiliki kemampuan pengetahuan dan keterampilan komunikasi yang tinggi dalam menyajikan presentasi hasil diskusi materi yang di bahas.

2. Disarankan pemberian materi dalam pembelajaran sejarah Indonesia, diharapkan dapat membuat suasana belajar yang menyenangkan, agar siswa merasa dirinya mampu ingin berusaha untuk menyelesaikan soal yang diberikan. Hendaknya guru dapat menjelaskan materi sesuai dengan kemampuan siswanya dan disarankan kepada guru ketika menggunakan pendekatan pembelajaran saintifik harus dibuat alokasi waktu yang tepat, efektif dan efisien sehingga tujuan pembelajaran tercapai.

3. Hendaknya dilakukan penelitian lanjutan, penelitian ini baru mengungkapkan sebagian kecil permasalahan yang berhubungan dengan pengetahuan dan keterampilan sejarah Indonesia siswa. Temuan penelitian menunjukkan masih banyak faktor yang mempengaruhi nilai pengetahuan dan keterampilan siswa yang tidak diungkapkan dalam penelitian ini.

\section{DAFTAR PUSTAKA}

Daryanto. (2014). Pendekatan Pembelajaran Saintifik Kurikulum 2013. Jakarta: Gava Media.

Dimyati dan Mudjiono. (2006). Belajar dan Pembelajaran. Jakarta: Rineka Cipta.

Dwi, A. dkk. (2014). Buku Guru Sejarah Indonesia Kelas X. Edisi Revisi. Jakarta: Kemendikbud.

Hamruni. (2012). Strategi Pembelajaran. Yogyakarta: Insan Madani.

Hasan, S.H. (2013). Informasi Kurikulum 2013. Bandung : Universitas Pendidikan Indonesia.

Majid, A. (2009). Perencanaan Pembelajaran. Bandung: PT Remaja Rosdakarya.

Surtikanti, dkk. (2008). Strategi Belajar Mengajar. Surakarta: UMS.

Wiyanarti, E. (2012). Model Pembelajaran Kontekstual dalam Pengembangan Pembelajaran Sejarah. Bandung : Universitas Pendidikan Indonesia 